\title{
What is National Forest Policy in Canada?
}

\author{
G. S. Nagle'
}

To begin, what is "national forest policy in any country?" Worrell defines it as a specification of "certain principles regarding the use of a society's forest resources which it is felt will contribute to the achievement of some of the objectives of that society". However, current, effective policy embraces not only these principles, written or unwritten, but also the whole set of "settled courses adopted and followed by society in dealing with the forest" (Worrell 1970).

We do have a set of "settled courses" in and around the forestry sector of Canada, and therefore we do have a national forest policy. Many of our past discussions have suffered from the pretense, or the misconception that a national forest policy would be some totally new weapon on the forestry battlefield. Even worse, the envisaged result was often static - a sort of Maginot Line to protect forest resources once and for all.

We have learned to our sorrow that the field is a complex, dynamic, and difficult one. It is wired with federal-provincial sensitivities and loaded with the explosive force of at least 100 key bureaucratic and political egos. It is set on the shifting sands of competing social and economic demands within Canada, and in our world markets.

Some of our perennial forestry problems are rooted in the feeling, nurtured in a relatively quiet, rural profession, that this is an unnatural and unreasonable state of affairs. Our refusal to recognize and accept the nature of the field often leads us to use inappropriate sensors, guidance, and transport systems to get us across even a small corner of the field. We are annoyed at changes in the rules of the game, and at any suggestion of temporary structures.

Canadian foresters do not have a monopoly on these problems. Johnston (1972) was speaking to foresters world-wide, and especially to those in countries with mostly public forests:

"... forest policy is formulated by governments and is based mainly on political considerations... Since government decisions are the results of political judgements which themselves are influenced by various competing or conflicting interests, forest policy cannot be evolved in isolation. It has to be integrated with policies in other sectors ... It is unrealistic to expect a forest policy to be stable for long periods of time. The social, economic, political, and technological structures of countries are liable to change rapidly. Forest policies ... have to be kept up to date."

${ }^{1}$ Consultant in forestry economics, Victoria, B.C., currently under contract as Project Director of the National Forest Policy Project of the Canadian Council of Resource and Environment Ministers.
In order to improve the national "forest policy set" in Canada, we must better define just what it is, at present. The current amalgam of more or less settled economic and political courses has been developing for many years, under many banners.

For the purpose of this brief discussion, I will group current issues and policies under four main headings:

- economics of the forestry sector
national economic strategy
federal/provincial powers
forestry agencies and foresters

\section{Economics of the Forestry Sector}

\section{Markets}

The forecast supply/demand position of each of our major markets - the USA, the EEC, and Japan indicates good prospects for increased imports of forest products. Canadian domestic demand is also forecast to increase substantially. The flexibility, renewability, and low energy inputs of forest products gives them a better than average chance in an uncertain future.

\section{Competitive Position}

Canada's sound technological position in the forest industry, our high quality fibre and the relative robustness of most of our soils and silvic systems, should keep us in the game in competition and in concert with most tropical producers, for the long run. Events in Russia, with the largest softwood reserves, can only be monitored and reacted to as they occur. Certainly they face formidable problems of access to their large eastern stocks, and rising domestic demands. We will always be filling the gaps in US, EEC, and Japanese production, at the margin. Each could produce more, but at increasing cost, and under increasing constraints imposed by their heavier populations.

\section{Industry Structures}

It is clear that the Canadian forest industry is not the picture of rosy-cheeked health, in all its regional segments. Many eastern pulp and paper mills, and many west-coast wood product mills are overdue for replacement. Labor relations, forest service relations, and public relations all need new methods of communication. Nonetheless, many new public - private planning initiatives are under way, and even the current industry structure has been able to compete successfully in world markets. Many of the industry's current problems are related to larger problems in the Canadian economy, and in the western world. 


\section{Resource Stocks and Flows}

Provincial forest inventories have been under constant review and revision for three decades. Each new cycle has revealed "new" resources in the form of trees and forests which were not counted in the previous cycle. In the latest cycle, for the first time, the calculated allowable annual cuts are not all enlarged, and some have been, or will be, reduced. The reasons for the down fall vary region by region, but most often:

- the logged lands have not been monitored very carefully for the timing, degree, and quality of reforestation;

- new computerized data handling techniques provide a better picture of resource flows over time;

- some forest land has been removed from the "harvestable" category.

Three issues have emerged regarding the status and trends of forest resources in Canada:

- a reforestation gap has developed which, unless corrected, will have serious impact on future output;

- the margin for expansion (or error) in the total softwood production is slim at present, and some sub-regions are currently harvesting more wood than is being grown;

- some local wood supply zones are approaching very lean years in the near future, due to age-class gaps in their forest. These nearterm gaps cannot be filled by reforestation.

These problems of future supply are being compounded by a shrinking forest land base. Hydro reservoirs, various utility corridors, watersheds, ecological/environmental reserves, new farms, ranches and parks all tend to draw from the productive forest land base, in their own expansions.

The resource squeeze implied in current trends could be alleviated by more intensive management of our forests. That is, by investing liquid capital in reforestation, stand improvement, and research/development projects (FLC Reed \& Assoc. 1978).

Many of the market and production questions which have been glossed over here will have to be the subject of continuing study and action, but if we can organize the resources and technology to intensify our silviculture, there will be little ground for sustained pessimism regarding the future of forestry output in Canada. Any need for a national forest policy, in the profession, has usually been perceived in these terms - a simple need for increased allocations to forest management and research, to maintain or increase wood output. But, as we are learning, there are other players in the game and they write most of the rules.

\section{National Economic Strategy}

\section{Sector Strategies}

For the past decade most governments in Canada (all levels) have been indicating a preference for economic activity other than the production of commodities (Miller 1977). A national stigma developed on "hewing wood and drawing water". Resource production activities were widely seen as having low technology, poor relative price performance, and high capital requirements per job created.

However, with stagflation (inflation in a stagnant economy, with high unemployment) becoming a way of life in the Canadian economy, some of the more facile economic assumptions are being abandoned, in favor of more detailed economic strategies, sector by sector. Forestry has been rediscovered on recent lists of sectors worthy of concentrated development effort, on a national scale (Economic Council 1977).

\section{Unemployment}

Unemployment, and under-employment of the working force, has been at epidemic proportions in Canada since the post-war wave of children began to reach the job market. Currently nearly $50 \%$ of our unemployed are $15-24$ years old. These young people are more educated than young workers of the past. Yet some analysts project a slowing growth rate for jobs requiring postsecondary education in the next decade (Statistics Canada 1978).

Together with native employment problems and special regional pockets of unemployment, this is the number one economic issue of the decade. There is no doubt that all levels of government take the problem seriously. For example, in 1979 the federal government will spend or send back to the provinces the following amounts for basically employment creation, or income support (Treasury Board 1978):

\$ billion

employment payments ........................... 1.8

veterans, natives, worker training ...... $\quad 1.0$

promote economic activity .................. 1.4

native and northern development ........ $\quad 0.7$

$\begin{array}{ll}\text { regional expansion and job creation .... } & 0.8\end{array}$

subsidies of oil imports, transportation, agriculture and fishing

TOTAL $\$ 9.2$ billion

These programs have been growing for a decade. It has seemed incongruous, at least to foresters, that the total capital re-invested in our public forests annually will hardly affect the rounding of the above sums.

There are increasing signs that the question of re-assessing these "make-work" and "transfer" programs is reaching the decision-making level. The Federal Provincial Conference of First Ministers in February 1978 concluded:

"Continuing attention will be given to the innovative use of Unemployment Insurance funds for productive employment and job creation."

Later, with specific reference to forestry, the First Ministers found a need for study of ..." "the 
possibility of reorienting Canada Works Programs ... (in the direction) ... of silviculture reforestation programs."

Currently, agreements are under discussion or completed between Canada Manpower and most provinces, under which this federal department will provide up to $\$ 8,100$ per man-year of employment in specified forestry programs.

The final impact of the latest federal budget reduction and job creation policies is not yet clear. However the direction seems to be towards creating jobs with marketable output. Forest resources could do well within this trend.

\section{Regional Development}

The federal Department of Regional Economic Expansion (DREE), and its precursors, have been deeply involved in rural land use and development, and therefore inevitably in forestry, for well over a decade. The long record of programs contains many examples of both the high promise and the high frustration of federal-provincial forestry agreements and joint programs in Canada.

From 1951 to 1967 the Federal Government contributed a total of $\mathrm{S} 64$ million to a series of shared-cost forestry agreements with the provinces. The Canada Land Inventory was also conducted in the 1960's, through a significant cooperative effort by both levels of government. Both efforts were basically discontinued in 1967 .

However, joint forestry agreements have staged a strong comeback in the 1970's, in the weaker regions, under DREE. The largest new source of forestry investment funds in recent years (perhaps $\$ 80$ million per annum by 1980 ) has been this Federal Department. Further investments in forestbased industries are also planned through DREE.

While it is generally agreed that such federal/ provincial development programs are beneficial, there is continuing discussion on all sides of the most appropriate DREE mechanisms, and of other federal/provincial avenues for regional investments in forestry (Canadian Council on Rural Development 1978).

\section{Federal/Provincial Powers}

One power which was clearly delegated to the provinces in the BNA Act of 1867 is the responsibility for forest resource management. Yet, if present trends continue, the federal government could be investing more money in the resource than the provinces, in the 1980's. The main allocations flow from national objectives regarding manpower, regional adjustment, and renewable energy.

There are of course other shifts in traditional federal-provincial roles. The most historic federal role in the forestry sector is in trade. Several provinces are increasing their activities in this field, both at home and abroad. The federal role closest to the trees is that of forestry and forest products research. Recently this historic effort has been squeezed into a decline within the "other" priorities of the new conglomerate Department of the Environment. At the same time, environmental protection initiatives increasingly involve the Department in regulating forest management, logging, and manufacturing practices.

Canada began as a true federation, not a union, and we are currently re-negotiating the federalprovincial sharing of many different revenues and responsibilities. At present the federal government annually collects about $\$ 1$ billion directly from the forestry sector, the provinces about $\$ 650$ million.

Explicit mechanisms and agencies are being developed for federal/provincial and inter-provincial discussions. A forester's book of acronyms must now include such new exotics as CIGS the Canadian Intergovernmental Conference Secetariat; FPRO - the Federal Provincial Relations Office of the Privy Council; TEGA - Treasury, Economic and Intergovernmental Affairs of Ontario; AI - Affaires Inter of Quebec; IR - Intergovernmental Relations in the Premier's Office of B.C.; and FIGA - Federal and Intergovernmental Affairs in Alberta.

Increased formalization of national forestry sector discussions and negotiations is inevitable, as a new form of national government is in the making, between the member Provinces of our Federation, and our joint Federal Government.

\section{Forestry Agencies, and Foresters}

One of our key sectoral problems is that, in some of our most important forestry agencies, a national viewpoint of forestry is regarded as more like the periscope of an enemy submarine than like the crow's nest of our own ship. Nonetheless, what national traffic, currents, horizons and storm signals can be discerned?

\section{Public Awareness}

The new public and political consciousness of forestry which has already been mentioned, is significant and nation-wide. As in all public policy issues, cause and effect are not clearly defined. Yet our profession has been mounting a fairly sustained, if uncoordinated, lobbying effort for several years. This effort is still far from peaking out. The Canadian Institute of Forestry, the Canadian Forestry Association, the provincial professional associations, the industry associations, the universities and technical schools, and others have been displaying a new determination to be heard, and some impressive new skills in the lobbying process.

\section{Institutions}

A second, and not unrelated trend across Canada, is rapid change in the big forest management agencies. The Provinces of British Columbia, Ontario and Quebec are re-designing their most basic forestry institutions, and planning/management systems. Increased forestry budgets have been allocated, with some federal participation. 
Every province is undergoing some process of review/change in their forestry administration, and raising the level of effort. Every province is refining its forestry information systems and economic targets for the sector, in order to move closer to a maximum economic benefit flow from its forest resources.

Every forestry agency in the country has burned its fingers in the hot kitchen of environmental dispute. New inter-departmental committee structures, and even advisory bodies with external, broad public representation, are flowering. The ultimate goals of a "conserver-society" are still not well formulated. It seems that we are in for a period of increasing realism about the speed at which society can change its basic production and consumption patterns. But the question of preserving a viable ecologic base for the long term will not go away (Goldsmith 1977). It is not a new question to foresters. All Canadians will have to learn more about the whole range of present costs of future resource flows.

The need for a leading research/development effort, in all these national trends, is clear and urgent. Yet this effort, at all levels, has been lost in a maze of institutional confusion and conflict. This inadequate performance exemplifies the key problem area in the forest policy field in Canada - the interface of various provincial and federal forestry institutions.

\section{The Not-So-New Frontier}

Many boundaries and separate realities must be recognized along the frontier between various provincial and federal forestry sector programs. But the total effect, and the interactions of all programs, have equal validity for Canadians. This fact has always been clear, but just who represented the national interest, and how it was to be made effective, has not been very clear.

Back in 1961, the national Resources for Tomorrow Conference addressed the issue, for all renewable resources, and the eleven governments founded the Canadian Council of Resource Ministers to provide a continuing forum for national discussions. Forestry issues were of the highest priority.

In the mid-1960's, a new cycle of forest inventories greatly expanded the horizon of available wood, and reduced the short-run concern. In the early 1970's, environmental concerns expanded, and the Council responded by broadening to become the Canadian Council of Resource and Environmental Ministers. Many important environment issues intruded, and forestry remained "on the back burner". By the late 1970's, the re-awakened concern over timber supply, and national forestry sector issues, spurred the Council to intensify its concern with forestry issues. After an interim review of existing policies (CCREM 1976), and consideration of a range of strategies, the Council initiated a national forest policy development project in late 1977 . The need is recognized to be urgent.
The socio-economic responsibility vested in the 10-12 resource ministers who control close to $95 \%$ of our forest land, is significant on any national scale. The members of this group, singly and in concert, exercise the dominant role in national forest policy by omission as well as commission. There is no way this responsibility can be passed on to one federal minister, or federal committee.

If national forest policy is made up largely of the decisions, and non-decisions, of these ministers, does our professional discontent stem mainly from decisions which we disagree with, or from questions that have not been put on the table? In my view, the important national issues have often been raised, but never addressed quite explicitly enough, by the 10-12 forestry ministers in concert.

They cannot write or execute taxation or trade policy, employment or regional development policy, housing policy, environment policy, transportation policy or labour policy. There is not always unanimity among forest resource ministers on these issues. The regions of Canada are engaged in broad competition with each other for many markets, and they often have different forestry priorities. Yet there are congruences in regional attitude to many of these policy sets. If the forest resource ministers could develop even a relatively unified position on a few of the most important issues, they could effectively bring to bear the weight of the largest manufacturing sector, the largest export sector, and the most geographically extensive sector in the national economy - the forestry sector.

Our profession must provide the necessary strategic designs and improved national structures, as well as detailed local plans, if we expect these ministers to better fulfill both regional and national mandates in forestry.

\section{Foresters}

Forestry principles, long term stability, technical forestry plans, long term programs, are deeply ingrained in our professional psyche. There are signs that we are learning some short-run tactics, but we must further refine our ability to react to today's economic and political forces, if we really seek improvement in Canadian forest policy, for the long term.

Useful devices would include:

- a more refined short term production strategy, made up of a series of fairly specific regional targets. This strategy must be broad enough to be comprehensible to economic planners, both provincial and federal;

- a more focused, better structured, more continuous effort by forestry agencies to monitor and influence programs with economic, regional, manpower, native welfare and other basic objectives in Canada;

- an improved pipeline of projects for each province/region which will offer greater flexibility in forestry sector responses to socio-economic initiatives by non-forestry agencies; 
- an improved international forestry intelligence effort, to collect and disseminate information on markets and supply developments, and conduct special studies on importable forest management technologies;

- better definition of forestry and forest products research/development responsibilites, and improved planning mechanisms in this field. A new "contract" need not be for all time, but improved definition for a decade at least could get this critical effort into the needed leadership role;

- improved federal/provincial management systems, through which monies from both levels of government can be disbursed to the vast rural regions of Canada, for local allocation and efficiency control. Top level management objectives and criteria (national) will have to be better defined and monitored for such systems to be operational;

- a continuing, well prepared forum for joint design and ministerial discussion of forestry sector goals and specific programs, and for joint reaction to external events and programs.

These few tools, formed and sharpened in the latter forum by un concertation, or joint accord among resource ministers, and coordinated with concurrent discussions among the First Ministers of Canada, could reshape the national forest policy set in this country. Without such mechanisms, the finest statement of national forestry principles for Canada might as well be stored in London, next to our absentee Constitution.

\begin{tabular}{|c|c|}
\hline CONSULTING & $\begin{array}{c}\text { Intistrial Forestry } \\
\text { FORESTERS } \\
\text { ENGINEERS }\end{array}$ \\
Centrally Located for \\
Western Canada's \\
Forest Industry \\
101. 1595 FIFTH AvE. \\
PRINCE GEORGE, B.c. \\
TEL.: 563-9207
\end{tabular}

\section{$\mathbf{k b m}$ FORESTRY CONSUITANTS INC.}

115 N. CUMBERLAND STREET THUNDER BAY, ONTARIO P7A 4M3 TEL: 344-0811

\author{
RESOURCE INVENTORY - \\ FOREST MANAGEMENT PLANNING \\ SILVICULTURAL SPECIALISTS \\ SYSTEM DESIGN AND CONTRACT
}

\section{References}

Canadian Council of Resource and Environment Ministers 1976. Forest Policies in Canada.

Volume I: Major objectives, problems and issues: identification and trends.

Volume II: A review of objectives, means, degree of success, impediments and anticipated changes by jurisdiction and program functions.

Volume III: Tabular statements by jurisdiction and program functions.

(Report of Task Force on Forest Policy, June 1976.)

Canadian Council on Rural Development. 1978. The relationship of Canada's forests to rural employment and community stability. CCRD/DREE Ottawa.

Canadian Forestry Association. 1978. Proc. of the national forest regeneration conference. Quebec City.

Economic Council of Canada. 1977. Fourteenth annual review - into the 1980's Government of Canada, Ottawa.

Federal Provincial Conference of First Ministers. 1978. Conclusions of the Ottawa Conference. Mimeo Document $800-7 / 078$.

F.L.C. Reed and Associations. 1978. Forest management in Canada, CFS Forest Management Institute Info. Report FMR. X. 102.

Goldsmith E. 1977. The future of an affluent society - the case of Canada. The Ecologist Vol. 7, No. 5, June 1977 p. 160-194 (Report Commissioned by the Advanced Concepts Centre of Environment Canada).

Johnston, D. R. 1972. The formulation and implementation of forest policy. Seventh World Forestry Congress; Buenos Aires.

Miller, C. George. 1977. Commodity investment in Canada: current issues. Seminar of Canadian Group of Trilateral Commission. Winnipeg. Queen's University, Centre for Resource Studies.

Statistics Canada (Zsigmond, Z.) 1978. Out of school, into the labor force. Government of Canada, Ottawa.

Treasury Board of Canada. 1978. Federal spending plans 1978-79. Government of Canada, Ottawa.

Worrell, A. C. 1970. Principles of forest policy. McGraw Hill Book Co., New York.

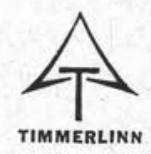

Tel.: (819) 326-3559

\section{TIMMERLINN UMMré}

PROFESSIONAL AND TECHNICAL SERVICES IN FORESTRY AND ENVIRONMENTAL SCIENCES

R.R. No. 2, STE. AGATHE DES MONTS, QUE. J8C $2 Z 8$

EDWARD

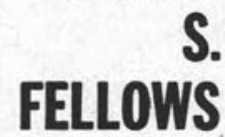

FORESTRY \& FOREST PRODUCTS CONSULTANT

P.O. Box 354, 404 Queen St., FREDERICTON, N. B.

Registered Professional Forester (N. B.) MEMBER:

Canadian Institute of Forestry

Forest Products Research Society, Etc.

INDUSTRY DEVELOPMENT - FOREST PRODUCTS ECONOMIC FOREST POLICY \& ADMINISTRATION 